\title{
Bioresorbable vascular stents and drug- eluting stents in treatment of coronary heart disease: a meta-analysis
}

\author{
Le $\mathrm{Ni}^{\dagger}$, Hao Chen ${ }^{\dagger}$, Zhurong Luo ${ }^{*}$ and Yunqiang $\mathrm{Yu}^{*}$
}

\begin{abstract}
Objective: To compare the efficacy and safety of bioresorbable vascular stents (BVS) and drug-eluting stents (DES) in coronary heart disease.

Methods: The full text of clinical studies involving BVS and DES was retrieved in PubMed, Springer, EMBASE, WileyBlackwell, and Chinese Journal Full-text Database. Review Manager 5.3 was used for meta-analysis to evaluate the risk of target lesion failure, stent thrombosis and cardiac death in BVS and DES.

Results: Finally, 10 studies with 6383 patients were included in the meta-analysis. Compared with DES group, BVS group had significantly increased risk of target lesion failure $(\mathrm{OR}=1.46,95 \% \mathrm{Cl} 1.20-1.79, P=0.0002$; $\mathrm{P}$ Heterogeneity $=$ $\left.0.68, I^{2}=0 \%\right)$, stent thrombosis $\left(\mathrm{OR}=2.70,95 \% \mathrm{Cl} 1.57-4.66, P=0.0003 ; \mathrm{P}\right.$ Heterogeneity $\left.=1.00, \mathrm{I}^{2}=0 \%\right)$ and cardiac death $\left(\mathrm{OR}=2.19,95 \% \mathrm{Cl} 1.17-4.07, P=0.01 ; \mathrm{P}\right.$ Heterogeneity $\left.=0.93, \mathrm{I}^{2}=0 \%\right)$.

Conclusion: This study shows that DES is a safer treatment than BVS for coronary revascularization.
\end{abstract}

Keywords: Bioresorbable vascular stents, Drug-eluting stents, Coronary heart disease, Meta-analysis

\section{Background}

Coronary heart disease (CHD), has been a leading cause of morbidity and mortality in the world [1,2]. The prevalence of CHD is increasing year by year and patients tend to be younger [3, 4]. Percutaneous coronary intervention (PCI) with stents is a common treatment strategy for CHD patients with significant stenosis of coronary arteries (>70\%). Nowadays, drug-eluting stents (DES) are widely used in PCI. Compared with previous bare metal stents, the obvious improvement of DES is the carriers of anti-proliferation drugs [5]. The drug carriers of DES are mainly polymer coatings, which are designed to carry enough drug dosage and can effectively control the decomposition, diffusion and release of paclitaxel or other drugs.

Bioabsorbable vascular stent (BVS) is a type of newly invented stent and theoretically have a number of potential benefits [6, 7]. First, the occlusion of coronary artery

\footnotetext{
* Correspondence: mdlzrong@126.com; a1501070@163.com

${ }^{\dagger}$ Le $\mathrm{Ni}$ and Hao Chen contributed equally to this work and should be considered co-first authors.

The 900th Hospital of PLA Joint Logistics Support Force, 156 West Second Ring Road, Fuzhou City, Fujian Province, China
}

can be opened by BVS implantation. Second, after being absorbed, BVS can restore normal vasomotion and endothelial function. In past several years, several clinical studies have been conducted to compare the efficacy of BVS with DES in parameters like target lesion failure. However, the outcomes were inconsistent and remain to be identified [8-11].

To establish the clinical efficacy of BVS, we conducted this meta-analysis of available randomized controlled trails (RCT) and clinical prospective studies comparing BVS and DES in CHD.

\section{Materials and methods}

\section{Search strategy}

The comparison between BVS and DES was comprehensively analyzed. Articles from inception to October 2018 were searched from PubMed, Springer, EMBASE, WileyBlackwell, and Chinese Journal Full-text Database. Systematic reviews and meta-analysis were conducted.

Two members of our team searched for articles independently using the following keywords: (1) bioresorbable stents OR BVS; (2) drug-eluting stents OR DES;

(c) The Author(s). 2020 Open Access This article is distributed under the terms of the Creative Commons Attribution 4.0 International License (http://creativecommons.org/licenses/by/4.0/), which permits unrestricted use, distribution, and 
(3) coronary heart disease OR CHD. All these terms are assembled with the connection symbol "and" to search the database for related articles. In order to obtain more relevant research and higher accuracy, the reference list of each article retrieved were also reviewed.

\section{Citation selection}

All articles after the first screening were further selected by two other authors. The titles and abstracts of these articles are independent and carefully screened. Then, if the research may be relevant, full-text research will be obtained.

The following inclusion criteria must be met in the citations included in this study:

(1) A randomized control trial study or a controlled clinical trial study;

(2) Comparison of the treatment between BVS and DES;
(3) Availability of full text.

\section{Exclusion criteria:}

(1) Observational studies;

(2) Studies on other treatments other than BVS or DES;

(3) Studies lacking outcome measures or comparable results.

Finally, the two authors jointly identified included articles. They examined whether the study met the above requirements. If there was any difference or no agreement was reached, the third investigator helped to make the decision.

\section{Data extraction}

Two reviewers read the full text and extracted the relevant data of each study into the coding table in

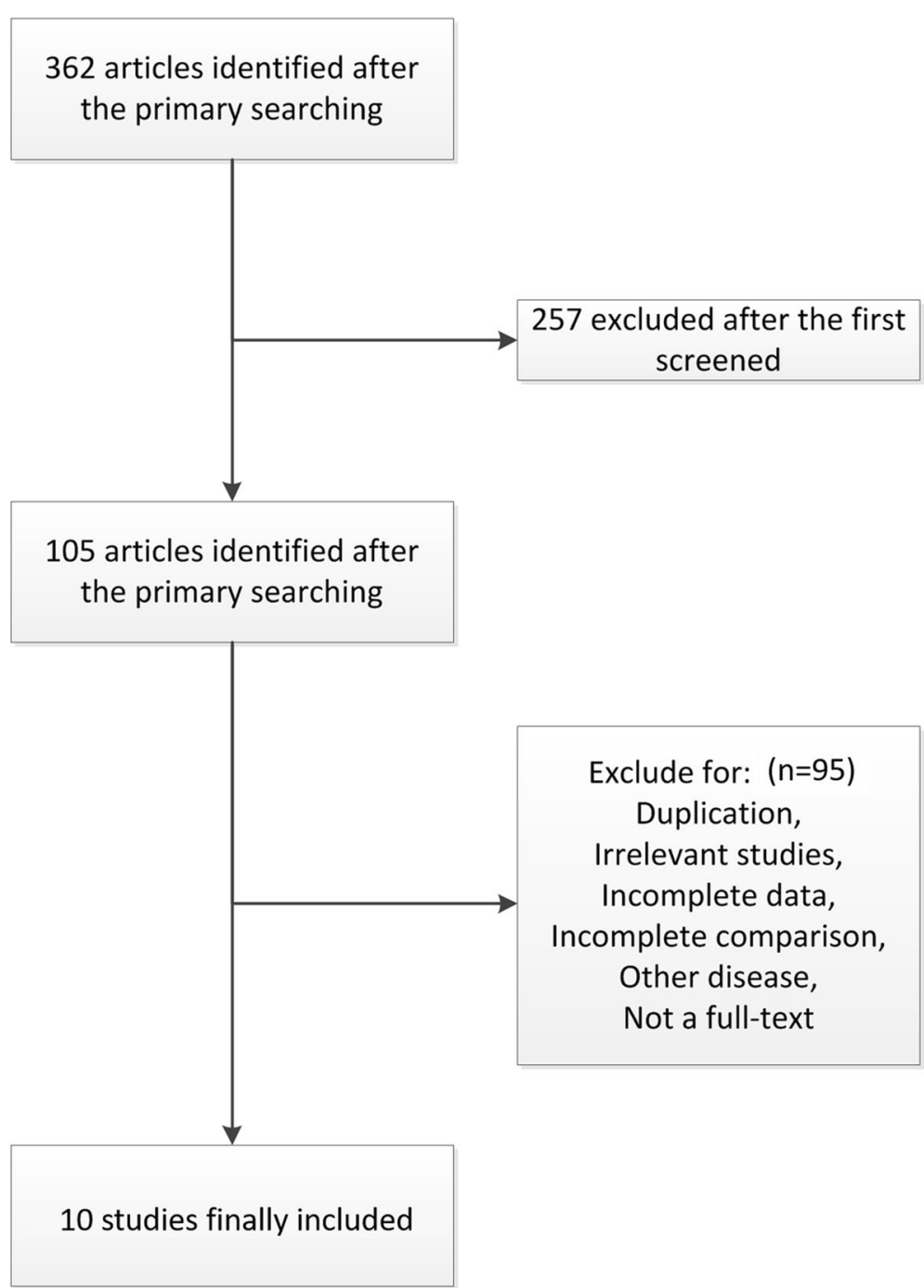

Fig. 1 Flow diagram of the study identification, inclusion and exclusion 
Table 1 Characteristic of the included studies

\begin{tabular}{|c|c|c|c|c|c|c|c|}
\hline Study & Year & Language & Country or Region & Age range (mean) & Groups & $\mathrm{n}$ & Years of onset \\
\hline \multirow[t]{2}{*}{ Abizaid } & \multirow[t]{2}{*}{2016} & \multirow[t]{2}{*}{ English } & \multirow[t]{2}{*}{ Brazil } & \multirow[t]{2}{*}{$62 \pm 10$} & BVS & 63 & \multirow[t]{2}{*}{ Nobember 2011 to JUne 2012} \\
\hline & & & & & DES & 63 & \\
\hline \multirow[t]{2}{*}{ Brugaletta } & \multirow[t]{2}{*}{2012} & \multirow[t]{2}{*}{ English } & \multirow[t]{2}{*}{ Netherlands } & \multirow[t]{2}{*}{$60.5 \pm 9.1$} & BVS & 17 & \multirow[t]{2}{*}{ January 2005 to December 2010} \\
\hline & & & & & DES & 18 & \\
\hline \multirow[t]{2}{*}{ Ellis } & \multirow[t]{2}{*}{2015} & \multirow[t]{2}{*}{ English } & \multirow[t]{2}{*}{ USA } & \multirow[t]{2}{*}{$63.5 \pm 10.6$} & BVS & 1322 & \multirow[t]{2}{*}{ NA } \\
\hline & & & & & DES & 686 & \\
\hline \multirow[t]{2}{*}{ Huang } & \multirow[t]{2}{*}{2018} & \multirow[t]{2}{*}{ English } & \multirow[t]{2}{*}{ Taiwan } & \multirow[t]{2}{*}{$56.7 \pm 3.4$} & BVS & 112 & \multirow[t]{2}{*}{ August 2012 to December 2014} \\
\hline & & & & & DES & 125 & \\
\hline \multirow[t]{2}{*}{ Kim } & \multirow[t]{2}{*}{2018} & \multirow[t]{2}{*}{ English } & \multirow[t]{2}{*}{ Korea } & \multirow[t]{2}{*}{$61.2 \pm 4.1$} & BVS & 232 & \multirow[t]{2}{*}{ January 2004 to January 2012} \\
\hline & & & & & DES & 232 & \\
\hline \multirow[t]{2}{*}{ Kim2 } & \multirow[t]{2}{*}{2018} & \multirow[t]{2}{*}{ English } & \multirow[t]{2}{*}{ Korea } & \multirow[t]{2}{*}{$64.3 \pm 6.7$} & BVS & 71 & November 2011 to December 2015 \\
\hline & & & & & DES & 87 & \\
\hline Puricel & 2015 & English & Switzerland & $64.1 \pm 5.9$ & BVS & 80 & January 2010 to January 2014 \\
\hline & & & & & DES & 80 & \\
\hline Sato & 2016 & English & Germany & $58.8 \pm 10$ & BVS & 45 & January 2010 to December 2014 \\
\hline & & & & & DES & 45 & \\
\hline Serruys & 2015 & English & Netherlands & $61.2 \pm 10.0$ & BVS & 335 & November 2011 to June 2013 \\
\hline & & & & & DES & 166 & \\
\hline Stone & 2018 & English & USA, Germany, Australia, & $63.1 \pm 10.1$ & BVS & 1296 & August 2014 to March 2017 \\
\hline & & & $\sin$ & & DES & 1308 & \\
\hline
\end{tabular}

Microsoft Excel software. The characteristics extracted in this study included the first author's name, publication year, year of onset, sample size (bioresorbable/drugeluting), age range of patients and outcome parameters. The parameters were about target lesion failure, stent thrombosis and cardiac death in BVS and DES.

\section{Statistical analysis}

Meta-analysis was performed by Revman 5.3 (Cochrane Collaboration, 2014) to assess differences in clinical efficacy between BVS and DES and to assess publication bias. $\mathrm{Q}$ statistics reflect the level of heterogeneity. When the heterogeneous $\mathrm{I}^{2}$ statistic was greater than $50 \%$ reflecting moderate or high heterogeneity, a random effect model was used, otherwise a fixed effect model was deployed.
We also performed a bias analysis of each study with the following criteria: (1) random sequence generation, (2) allocation concealment, (3) blinding of participants and personnel, (4) blinding of outcome assessment, (5) incomplete outcome data, (6) selective reporting, and (7) other bias. In our studies, all parameters are two variables and the corresponding risk of $95 \%$ confidence interval (CIS) is calculated (RR). Funnel plots together with Egger tests were also applied to assess possible publication bias. $P$ value $<0.05$ was considered that statistically significant was observed.

\section{Results}

Search results

A total of 362 related articles were found in the preliminary search of electronic database. After a thorough review,

Table 2 The risk of bias table in this study

\begin{tabular}{lllllllllll}
\hline & Abizaid & Brugaletta & Ellis & Huang & Kim & Kim2 & Puricel & Sato & Serruys & Stone \\
\hline Random sequence generation & low & not & high & not & low & low & high & high & low & high \\
Allocation concealment & low & low & high & high & high & high & low & low & low & high \\
Blinding of participants and personnel & high & high & high & high & high & high & high & high & high & high \\
Blinding of outcome assessment & not & low & high & high & low & low & low & low & not & high \\
Incomplete outcome data & not & low & high & low & not & not & low & low & low & high \\
Selective reporting & high & high & high & not & low & low & low & not & low & high \\
Other bias & not & low & high & not & low & low & not & not & low & high \\
\hline
\end{tabular}

Note: in this table, "low" stands for "low risk", "high" stands for "high risk", "not" stands for "not clear" 


\begin{tabular}{|c|c|c|c|c|c|c|c|c|c|c|}
\hline Studv or Subgroup & $\begin{array}{c}\text { BVS } \\
\text { Events }\end{array}$ & $\mathbf{S}$ & \multicolumn{2}{|c|}{ DES } & Weight & $\begin{array}{c}\text { Odds Ratio } \\
\text { M-H, Fixed, } 95 \% \mathrm{Cl}\end{array}$ & \multicolumn{4}{|c|}{$\begin{array}{c}\text { Odds Ratio } \\
\text { M-H, Fixed, 95\% Cl }\end{array}$} \\
\hline Stone 2018 & 98 & 1296 & 82 & 1308 & $46.5 \%$ & $1.22[0.90,1.66]$ & & & 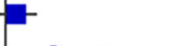 & \\
\hline Serruys 2015 & 34 & 335 & 8 & 166 & $5.9 \%$ & $2.23[1.01,4.93]$ & & & & \\
\hline Sato 2016 & 4 & 45 & 3 & 45 & $1.7 \%$ & $1.37[0.29,6.48]$ & & & & \\
\hline Puricel 2015 & 9 & 80 & 6 & 80 & $3.3 \%$ & $1.56[0.53,4.62]$ & & & & \\
\hline Kim2 2018 & 6 & 71 & 4 & 87 & $2.0 \%$ & $1.92[0.52,7.07]$ & & & & \\
\hline Kim 2018 & 21 & 232 & 10 & 232 & $5.6 \%$ & $2.21[1.02,4.80]$ & & & & \\
\hline Huang 2018 & 11 & 112 & 5 & 125 & $2.6 \%$ & $2.61[0.88,7.77]$ & & & & \\
\hline Ellis 2015 & 102 & 1313 & 41 & 677 & $30.7 \%$ & $1.31[0.90,1.90]$ & & & 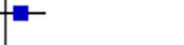 & \\
\hline Brugaletta 2012 & 3 & 17 & 1 & 18 & $0.5 \%$ & $3.64[0.34,39.01]$ & & & & \\
\hline Abizaid 2016 & 6 & 63 & 2 & 63 & $1.1 \%$ & $3.21[0.62,16.56]$ & & & & \\
\hline Total $(95 \% \mathrm{Cl})$ & & 3564 & & 2801 & $100.0 \%$ & $1.46[1.20,1.79]$ & & & $\bullet$ & \\
\hline Total events & 294 & & 162 & & & & & & & \\
\hline $\begin{array}{l}\text { Heterogeneity: } \mathrm{Chi}^{2}= \\
\text { Test for overall effect }\end{array}$ & $\begin{array}{l}6.58, \mathrm{df}= \\
Z=3.700\end{array}$ & $\begin{array}{l}9(P= \\
P=0.0\end{array}$ & $\begin{array}{l}0.68) ; 1^{2}= \\
002)\end{array}$ & $=0 \%$ & & & 0.01 & $\begin{array}{l}0.1 \\
\text { Favours BVS }\end{array}$ & $1 \frac{10}{\text { Favours DES }}$ & 100 \\
\hline
\end{tabular}

10 papers eventually met all inclusion criteria [8-17]. The other 352 articles were excluded due to duplication, article types, irrelevant studies, no control groups, incomplete data or comparisons. Figure 1 is a flowchart of identification, inclusion and exclusion, reflecting the search process and the reasons for exclusion.

\section{Characteristics of included studies}

Table 1 lists the first author's name, year of publication, sample size (bioresorbable/drug-eluting), age range of patients, and outcome parameters for each study. All these articles were published from 2010 to 2018. The sample size is between 35 and 2604. At last, 6383 patients with coronary heart disease, including 3573 in BVS group and 2810 in DES group were included in our meta-analysis.

\section{Quality assessment}

The deviation table in the Review Manager 5.3 tutorial is used to assess the risk of each study by applying the criteria for evaluating design-related deviations. The risk of bias in this study is listed in Table 2. Participants and respondents had a high risk of blindness due to significant differences between bioresorbable group and drug-eluting group.

\section{Results of meta-analysis}

\section{Meta-analysis about target lesion failure}

Ten studies involved target lesion failure. All 10 studies showed statistically significant differences in target lesion failure between BVS and DES. The meta-analysis suggested that the target lesion failure of the BVS group was significantly higher than that of DES group with no heterogeneity among studies $(\mathrm{OR}=1.46$, 95\% CI 1.20 $1.79, P=0.0002 ; \mathrm{P}_{\text {Heterogeneity }}=0.68, \mathrm{I}^{2}=0 \%$; Fig. 2 ).

\begin{tabular}{|c|c|c|c|c|c|c|c|c|c|c|c|}
\hline Studv or Subgroup & $\begin{array}{l}\text { BVS } \\
\text { Events }\end{array}$ & Total & $\begin{array}{l}\text { DES } \\
\text { Events }\end{array}$ & Stotal & Weight & $\begin{array}{c}\text { Odds Ratio } \\
\text { M-H, Fixed, } 95 \% \mathrm{Cl}\end{array}$ & & & $\begin{array}{r}\text { Odds I } \\
\text { M-H, Fixe }\end{array}$ & $\begin{array}{l}\text { Ratio } \\
\text { d, } 95 \% \mathrm{Cl}\end{array}$ & \\
\hline Abizaid 2016 & 2 & 63 & 1 & 63 & $5.2 \%$ & $2.03[0.18,23.01]$ & & & & & \\
\hline Brugaletta 2012 & 2 & 17 & 1 & 18 & $4.6 \%$ & $2.27[0.19,27.58]$ & & & & & \\
\hline Ellis 2015 & 20 & 1301 & 5 & 675 & $35.0 \%$ & $2.09[0.78,5.60]$ & & & & $\rightarrow$ & \\
\hline Huang 2018 & 5 & 112 & 2 & 125 & $9.8 \%$ & $2.87[0.55,15.12]$ & & & - & & \\
\hline Kim 2018 & 6 & 232 & 2 & 232 & $10.5 \%$ & $3.05[0.61,15.29]$ & & & - & & \\
\hline Kim2 2018 & 2 & 71 & 1 & 87 & $4.7 \%$ & $2.49[0.22,28.07]$ & & & & & \\
\hline Puricel 2015 & 2 & 80 & 0 & 80 & $2.6 \%$ & $5.13[0.24,108.51]$ & & & & & $\rightarrow$ \\
\hline Sato 2016 & 1 & 45 & 0 & 45 & $2.6 \%$ & $3.07[0.12,77.32]$ & & & & & \\
\hline Serruys 2015 & 9 & 335 & 0 & 166 & $3.5 \%$ & $9.69[0.56,167.49]$ & & & - & & $\longrightarrow$ \\
\hline Stone 2018 & 9 & 1296 & 4 & 1308 & $21.4 \%$ & $2.28[0.70,7.42]$ & & & & 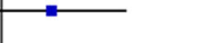 & \\
\hline Total $(95 \% \mathrm{Cl})$ & & 3552 & & 2799 & $100.0 \%$ & $2.70[1.57,4.66]$ & & & & & \\
\hline Total events & 58 & & 16 & & & & & & & & \\
\hline $\begin{array}{l}\text { Heterogeneity: } \mathrm{Chi}^{2}= \\
\text { Test for overall effect: }\end{array}$ & $\begin{array}{l}1.39, \mathrm{df}= \\
Z=3.58(F\end{array}$ & $\begin{array}{l}9(P=1 \\
P=0.00\end{array}$ & $\begin{array}{l}1.00) ; r^{2}= \\
003)\end{array}$ & & & & 0.01 & $\begin{array}{l}0.1 \\
\text { Favours }\end{array}$ & Is [BVS] ${ }^{1}$ & $\begin{array}{c}10 \\
\text { Favours [DES] }\end{array}$ & $100^{\circ}$ \\
\hline
\end{tabular}




\begin{tabular}{|c|c|c|c|c|c|c|c|c|c|c|}
\hline Studv or Subgroup & $\begin{array}{l}\text { BVS } \\
\text { Events }\end{array}$ & Total & $\begin{array}{l}\text { DES } \\
\text { Events }\end{array}$ & Total & Weight & $\begin{array}{c}\text { Odds Ratio } \\
\text { M-H, Fixed, } 95 \% \mathrm{Cl}\end{array}$ & & $\begin{array}{r}\text { Odds } \\
\text { M-H, Fixe }\end{array}$ & $\begin{array}{l}\text { Ratio } \\
\text { d, } 95 \% \mathrm{Cl}\end{array}$ & \\
\hline Abizaid 2016 & 1 & 63 & 0 & 63 & $3.3 \%$ & $3.05[0.12,76.26]$ & & & & \\
\hline Brugaletta 2012 & 1 & 17 & 0 & 18 & $3.0 \%$ & $3.36[0.13,88.39]$ & & & & \\
\hline Ellis 2015 & 8 & 1313 & 1 & 677 & $8.9 \%$ & $4.14[0.52,33.20]$ & & & & \\
\hline Huang 2018 & 1 & 112 & 1 & 125 & $6.3 \%$ & $1.12[0.07,18.07]$ & & & & \\
\hline Kim 2018 & 4 & 232 & 0 & 232 & $3.3 \%$ & $9.16[0.49,171.06]$ & & & & \\
\hline Kim2 2018 & 1 & 71 & 0 & 87 & $3.0 \%$ & $3.72[0.15,92.81]$ & & & & \\
\hline Puricel 2015 & 2 & 80 & 0 & 80 & $3.3 \%$ & $5.13[0.24,108.51]$ & & & & \\
\hline Sato 2016 & 1 & 45 & 1 & 45 & $6.6 \%$ & $1.00[0.06,16.50]$ & & & & \\
\hline Serruys 2015 & 5 & 335 & 1 & 166 & $8.9 \%$ & $2.50[0.29,21.57]$ & & & & \\
\hline Stone 2018 & 10 & 1296 & 8 & 1308 & $53.4 \%$ & $1.26[0.50,3.21]$ & & & & \\
\hline Total $(95 \% \mathrm{Cl})$ & & 3564 & & 2801 & $100.0 \%$ & $2.19[1.17,4.07]$ & & & & \\
\hline Total events & 34 & & 12 & & & & & & & \\
\hline \multicolumn{7}{|c|}{$\begin{array}{l}\text { Heterogeneity: } \text { Chi }^{2}=3.66, d f=9(P=0.93) ; I^{2}=0 \% \\
\text { Test for overall effect: } Z=2.47(P=0.01)\end{array}$} & 0.01 & $\begin{array}{l}0.1 \\
\text { Favours [BVS] }\end{array}$ & Favours [DES] & $100^{\circ}$ \\
\hline
\end{tabular}

\section{Meta-analysis about the stent thrombosis}

The forest plot for meta-analysis about the stent thrombosis was presented in Fig. 3. The results demonstrated that the stent thrombosis in BVS group was significantly higher than that of DES group with no heterogeneity among studies $(\mathrm{OR}=2.70,95 \% \mathrm{CI} 1.57-4.66, P=0.0003$; $\mathrm{P}_{\text {Heterogeneity }}=1.00, \mathrm{I}^{2}=0 \%$; Fig. 3 ).

\section{Meta-analysis about the cardiac death}

All included studies about the cardiac death was shown in Fig. 4. The overall result indicated that the cardiac death in BVS was significantly higher than that of DES group with no heterogeneity among studies $(\mathrm{OR}=2.19,95 \% \mathrm{CI}$ 1.17-4.07, $P=0.01$; $P_{\text {Heterogeneity }}=0.93, \mathrm{I}^{2}=0 \%$; Fig. 4).

\section{Bias analysis}

Funnel plots of target lesion failure in bioresorbable and drug-eluting was performed. All studies are included in the plot. The results showed that the funnel plot had medium symmetry and little publication bias (Fig. 5).

\section{Discussion}

CHD is mainly caused by abnormal lipid metabolism, which leads to accumulation of lipid in intima of arteries, and then causes a series of ischemic symptoms $[14,18]$. With the transformation of dietary structure and the acceleration of aging, the incidence of CHD showed a significant rising trend and has become a heavy disease

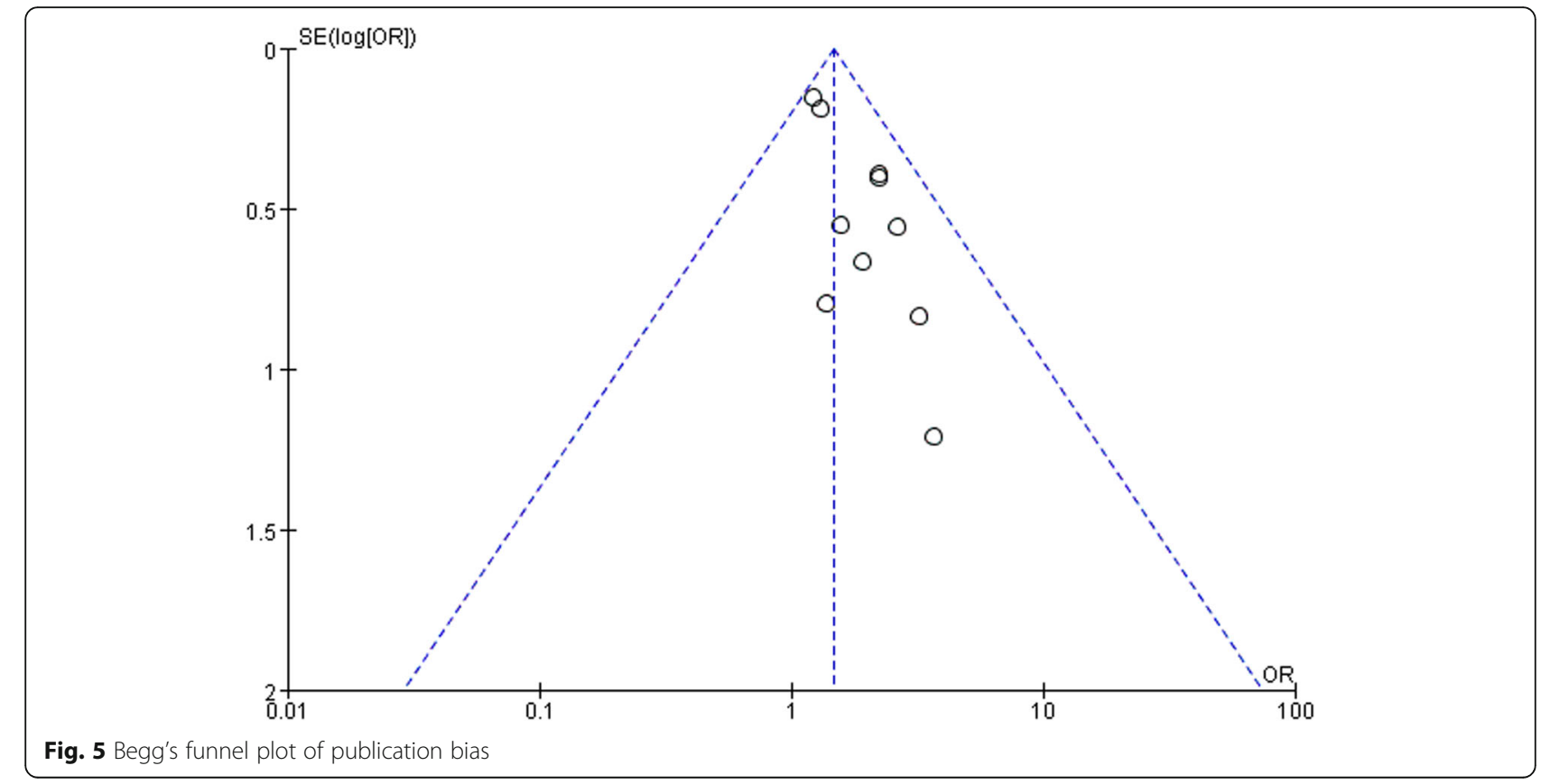


burden to the society. For patients with obstructive CHD, stents implantation is an effective therapy to maintain normal coronary circulation.

DES surface coating of high molecular polymer contains anti-smooth muscle proliferation drugs [19-21]. Contemporary DES has better clinical outcomes than bare-metal stents, but there are still risks of stent stenosis and thrombosis due to persistent inflammation, loss of normal vessel curvature and so on [22, 23]. In view of this, BVS was invented to provided mechanical support like DES for 1 year, followed by complete bio-resorption over several years. Several large RCTs showed BVS was noninferior to DES with respect to symptoms control. However, its safety remains to be established.

In our meta-analysis, BVS had a significantly higher risk of target lesion failure, stent thrombosis and cardiac death than DES at 1 year, which indicated that BVS was not as safe as DES. All these results demonstrated that DES was a better therapy than BVS for coronary revascularization. In fact, the AIDA study and ABSORB III study both demonstrated an increased risk of scaffold thrombosis $[24,25]$. BVS is, by design and performance, more thrombogenic than current DES. The reasons for higher rate of thrombosis with BVS were not fully clear and some concerns have been raised about the optimal preparation of the lesion and insufficient post-dilatation [26]. In addition, the latest guidelines on coronary revascularization does not support the use of BVS with a class III level of evidence $C$ recommendation [27]. Therefore, interventionalist should be aware of the possible risks related to the use of BVS.

Some limitations existed in this research. First, the present number of studies on BVS is still limited especially in outcome analysis. Second, most of the studies included were investigating 'Absorb BVS' device. New BVS with a smaller footprint, less thrombogenicity (e.g., magnesium), faster reabsorption and advanced mechanical properties is under development. We cannot dismiss the safety and efficacy of new BVS technology.

\section{Conclusion}

BVS had a significantly higher risk of target lesion failure, stent thrombosis and cardiac death than DES. DES is a safer treatment strategy than BVS for coronary revascularization.

\section{Abbreviations}

BVS: Bioresorbable vascular stents; CHD: Coronary heart disease; DES: Drugeluting stents

\section{Acknowledgements}

Not applicable.

\section{Authors' contributions}

YY designed, coordinated, and collected the data for the review. ZL assisted with the data extraction and analysis. LN assisted with the study selection and quality assessment. HC was involved as the third reviewer to solve disagreement when necessary. HC provided general advice and assisted with the writing of the review. All authors read and approved the final manuscript.

\section{Funding}

Not applicable.

\section{Availability of data and materials \\ Not applicable.}

\section{Ethics approval and consent to participate}

Not applicable.

\section{Consent for publication}

Not applicable.

\section{Competing interests}

We declare that we do not have any commercial or associative interest that represents a conflict of interest in connection with the work submitted.

Received: 19 February 2019 Accepted: 2 January 2020

Published online: 28 January 2020

\section{References}

1. Arturo $G$, et al. Successful treatment of recurrent carotid in-stent restenosis and drug-eluting balloon failure with a coronary bioresorbable vascular scaffold: a case report. Int J Surg Case Rep. 2016;21:78-82.

2. Chan $\mathrm{W}$, et al. Complex coronary artery bifurcation treatment utilizing everolimus-eluting bioresorbable vascular scaffolds and optical coherence tomography. Coron Artery Dis. 2014;25(7):629-31.

3. Dalos $D$, et al. Mechanical properties of the everolimus-eluting bioresorbable vascular scaffold compared to the metallic everolimus-eluting stent. BMC Cardiovasc Disord. 2016;16(1):104.

4. Dudek D, et al. Four-year clinical follow-up of the ABSORB everolimuseluting bioresorbable vascular scaffold in patients with de novo coronary artery disease: the ABSORB trial. Eurolntervention. 2012;7(9):1060-1.

5. Nef $\mathrm{H}$, et al. Evaluation of the short- and long-term safety and therapy outcomes of the everolimus-eluting bioresorbable vascular scaffold system in patients with coronary artery stenosis: rationale and design of the German-Austrian ABSORB ReglstRy (GABI-R). Cardiovasc Revasc Med. 2016; 17(1):34-7.

6. lelasi A, Tespili M. Current and future perspectives on drug-eluting bioresorbable coronary scaffolds. Futur Cardiol. 2014;10(3):409-20.

7. Kimura T, et al. A randomized trial evaluating everolimus-eluting absorb bioresorbable scaffolds vs. everolimus-eluting metallic stents in patients with coronary artery disease: ABSORB Japan. Eur Heart J. 2015;36(47):3332-42

8. Abizaid AMP, et al. Serial multimodality imaging and 2-year clinical outcomes of the novel DESolve Novolimus-eluting Bioresorbable coronary scaffold system for the treatment of single De novo coronary lesions. J Am Coll Cardiol Intv. 2016:9(6):565-74.

9. Brugaletta $\mathrm{S}$, et al. Analysis of 1 year virtual histology changes in coronary plaque located behind the struts of the everolimus eluting bioresorbable vascular scaffold. Int J Cardiovasc Imaging. 2012;28(6):1307-14.

10. Ellis SG, et al. Everolimus-eluting Bioresorbable scaffolds for coronary artery disease. N Engl J Med. 2015;373(20):1905-15.

11. Huang $L$, et al. Hemocompatibility and anti-fouling behavior of multilayer biopolymers immobilized on gold-thiolized drug-eluting cardiovascular stents. Colloids Surf B: Biointerfaces. 2019;173:470-7.

12. Kim DW, Her SH, Park HW. Incremental age-related one-year MACCE after acute myocardial infarction in the drug-eluting stent era (from KAMIR-NIH registry). J Geriatr Cardiol. 2018;15:574-84.

13. Kim YH, Her AY, Rha SW. Five-year major clinical outcomes between firstgeneration and second-generation drug-eluting stents in acute myocardial infarction patients underwent percutaneous coronary intervention. J Geriatr Cardiol. 2018;15:523-33.

14. Puricel S, et al. Comparison of Everolimus- and Biolimus-eluting coronary stents with Everolimus-eluting Bioresorbable vascular scaffolds. J Am Coll Cardiol. 2015:65(8):791-801.

15. Sato T, et al. The fate of incomplete scaffold apposition of everolimuseluting bioresorble scaffolds: a serial optical coherence tomography analysis. J Cardiol. 2017;70(5):454-60. 
16. Serruys PW, et al. A bioresorbable everolimus-eluting scaffold versus a metallic everolimus-eluting stent for ischaemic heart disease caused by denovo native coronary artery lesions (ABSORB II): an interim 1-year analysis of clinical and procedural secondary outcomes from a randomised controlled trial. Lancet. 2015;385(9962):43-54.

17. Stone GW, et al. Blinded outcomes and angina assessment of coronary bioresorbable scaffolds: 30-day and 1-year results from the ABSORB IV randomised trial. Lancet. 2018;392(10157):1530-40.

18. Rizik DG, Hermiller JB, Kereiakes DJ. Bioresorbable vascular scaffolds for the treatment of coronary artery disease: clinical outcomes from randomized controlled trials. Catheter Cardiovasc Interv. 2016;88(S1):21-30.

19. Waksman R. A new generation of drug-eluting stents: indications and outcomes of bioresorbable vascular scaffolds. Cleve Clin J Med. 2017:84(12 Suppl 4):e20-4.

20. Wiebe J, Nef HM, Hamm CW. Current status of bioresorbable scaffolds in the treatment of coronary artery disease. J Am Coll Cardiol. 2014;64(23):2541-51.

21. Zhang $Y$, et al. Bioresorbable scaffolds in the treatment of coronary artery disease. Med Devices (Auckl). 2013;6:37-48.

22. Onuma $Y$, et al. Incidence and imaging outcomes of acute scaffold disruption and late structural discontinuity after implantation of the absorb Everolimus-eluting fully bioresorbable vascular scaffold: optical coherence tomography assessment in the ABSORB cohort B trial (a clinical evaluation of the bioabsorbable Everolimus eluting coronary stent system in the treatment of patients with De novo native coronary artery lesions). JACC Cardiovasc Interv. 2014;7(12):1400-11.

23. Pichette M, Chevalier F, Genereux P. Coronary artery perforation at the level of two-overlapping bioresorbable vascular scaffolds: the importance of vessel sizing and scaffold thickness. Catheter Cardiovasc Interv. 2015;86(4):686-91.

24. Wykrzykowska JJ, et al. Bioresorbable scaffolds versus metallic stents in routine PCl. N Engl J Med. 2017;376(24):2319-28.

25. Kereiakes DJ, et al. 3-year clinical outcomes with Everolimus-eluting Bioresorbable coronary scaffolds: the ABSORB III trial. J Am Coll Cardiol. 2017;70(23):2852-62

26. Mangieri A, Colombo A. Should we stop using bioresorbable scaffolds in coronary revascularisation? Eurolntervention. 2019:15(1):28-30.

27. Neumann FJ, et al. 2018 ESC/EACTS Guidelines on myocardial revascularization. Eur Heart J. 2019:40(2):87-165.

\section{Publisher's Note}

Springer Nature remains neutral with regard to jurisdictional claims in published maps and institutional affiliations.

Ready to submit your research? Choose BMC and benefit from:

- fast, convenient online submission

- thorough peer review by experienced researchers in your field

- rapid publication on acceptance

- support for research data, including large and complex data types

- gold Open Access which fosters wider collaboration and increased citations

- maximum visibility for your research: over $100 \mathrm{M}$ website views per year

At $\mathrm{BMC}$, research is always in progress.

Learn more biomedcentral.com/submissions 